\title{
Somalia 2007: Starting from scratch on the long and winding road to peace and democracy?
}

\author{
Adrienne Ansems \\ Department of Sociology and Social Anthropology, \\ Stellenbosch University ${ }^{1}$
}

\section{Introduction}

Somalia, a country composed of four and a half major tribes, namely the Hawiye, centred in Mogadishu, the Darod based in the North, the Dir and the Rahanweyn (the other 40-odd minor tribes falling into the "half" category) blundered into the $21^{\text {st }}$ century without a modern state or its institutions (Mbugua, 2004:26). While the country has been without an effective government since 1991, recent reports suggest that, unless immediate action is taken on an international scale, Somalia will continue on its downward trend towards internal collapse. Although much hope was pinned on the success of the Somali National Reconciliation Conference, which played host to more than 1325 delegates from a selection of Somalia's various regions and clans to talk about and propose solutions to Somalia's protracted problems, the conference was concluded on 30 August 2007 showing little for participants' efforts. This initiative came after a spate of fighting in Somalia that has not only been labelled the "worst violence in Somalia's 16 years of war and turmoil", but also, "the worst single displacement of people this year anywhere in the world" (Nordland, 2007:60).

Meanwhile, Ethiopian troops remain bogged down in Somalia as the promised AU troops fail to materialise (BBC News 24, 2007b). The reluctance of the UN Security Council to deploy a peacekeeping force to Somalia to create stability in the country is based on the principle that there first has to be some measure of peace as well as an agreement among clans concerning the way forward.

1 Adrienne Ansems is a student in the Department of Sociology and Social Anthropology, University of Stellenbosch. Acknowledgement is hereby given to Prof Lindy Heinecken for guidance and revision of previous versions of this article. 


\section{6}

Easily forgotten by some is the acknowledgement that attempts at establishing peace and democracy rest on the creation of mutually acceptable principles of good governance, incorporating respect for human rights. While many may doubt whether democracy is feasible or possible in Africa, research in fact reveals that "since 1990, civilian, constitutional systems have become common across the continent, effectively eclipsing the military and single party dictatorships that came before" (Bratton, 2005:12). Democracy has been reached in countries like Benin, Ghana, Senegal, Mauritius and Mali, where post-transitional elections have paved the way for a peaceful transition of ruling parties.

The question remains, why is democracy, literally translating to "rule of the people", recognised as the preferred system of governance in Africa? While the term 'democracy' has at times been criticised for meaning "anything to anyone and thus nothing at all", it is generally thought to encompass a political system in which power is exercised by the people as a whole, whether by means of representative or participatory mechanisms. Democracy incorporates rule by consent, general consultation and majority decision-making. Law-protected rights are an important feature of any true democracy, and it remains the government's duty to respect and uphold human rights, diversity and egalitarianism.

In weak states, governments generally have an inability to exercise control and authority over their rural regions, urban areas and borders, which increases governments' susceptibility to domestic threats. Furthermore, such governments frequently lack social cohesion and consensus on what organising principles should allow for the contest of state power and how such power should be executed (Ohlson and Soderberg, 2003:6). The legitimacy of such governments is also often undermined by governments' inability to protect the public and to attend to the public's wellbeing, and to counter external economic and political threats. Where states display such characteristics, it is difficult to shift towards or maintain a democratic nation state. In fact, Bratton (2005:14) claims that a fully-fledged functioning democracy has never emerged in any of Africa's weaker states. Most African states seem capable of nurturing only "partly free" or "un-free" political regimes, which are easily destabilised by mass uprisings, military coups, terrorism, crime and disease.

Much of what has been defined above is characteristic of Somalia, a country crippled by war, inter-clan rivalry and state weakness. So what are the prospects for Somalia, a country literally starting from scratch to achieve peace and the "democratic ideal"? Has Somalia ever had an effective democratic government and if so, where did things go wrong? To this end, the first section of this article chronicles the historic socio-political background of Somalia, before moving on to more recent events which have led to the takeover by the Islamic Courts Union (ICU) of government and the subsequent attempts to restore stability in this fragile state. Major role-players, 


\section{7}

internal as well as external to the country, are listed, as are various anticipated scenarios and recommendations for peace and democracy. To add a citizen's voice to the debate, a number of Somali immigrants living in South Africa were interviewed to reflect on how they view the prospects of peace, stability and democracy in their country of origin. ${ }^{2}$

\section{Historical background}

Like much of Africa, the impact of colonialism left its imprint on Somalia. During the time of colonialism, the European powers - France, Britain and Italy divided the Somali nation amongst themselves, partitioning Somalia into five separate parts or "protectorates". While one portion remained under the control of Kenya, the Ogaden province was given to Ethiopia's King Menelik by the British Empire. Although British Somaliland and Italian Somaliland were united at independence on 1 July 1960, the French kept Djibouti under colonial administration, and the region did not gain independence until 1977 (Elmi and Barise, 2006:36). The effects of this partitioning continue to permeate Somali society today. A substantial minority of Somalis fall outside the country's boundaries while the northern region of Somalia (former British Somaliland) continues to push for a withdrawal from the south (Buzan, 1991:75). In this regard, colonialism is said to have had a permanently damaging effect on the Somali people, Somalia's socio-economic system and attempts at post-independence reconstruction. Colonialism, however, is not the only factor contributing to Somalia's collapse.

Ongoing clan wars over resources such as grazing land and water existed long before Somalia became unified as a nation state. However, after Somalia gained independence, many Somalis moved to the urban areas where a new realisation surfaced around the type of resources needed to prosper and the means to secure them. Here the control of the nation's resources (government resources, control of foreign aid, appointments of civil servants) was equated with control of the state (Elmi and Barise, 2006:33). Although Somalia's first government, under president Aden Abdullah Osman, was generally recognised as democratic, corruption and political patronage appointments soon affected all levels of government and its legitimate authority.

During this so-called democratic era (1960-1969), the state soon failed to meet the expectations of various segments of society, making way for a military coup under General Siad Barre in October 1969. Typical of such authoritarian dictatorships, Barre

\footnotetext{
${ }^{2}$ Six male Somali shopkeepers and stall owners were interviewed by way of informal conversations in Stellenbosch on 7 July 2007.
} 


\section{8}

displayed little toleration of opposition groups or criticism of the new leadership. In response to such authoritarianism, various guerrilla opposition movements were founded between 1978 and 1989, and after the 1977/1978 war between Somalia and Ethiopia, a number of military officers attempted to overthrow the government. When an armed struggle started against the military regime, Ethiopia welcomed and armed opposition groups fleeing from the repression, glad for the opportunity to back the opposition of the state with which it had largely interacted on hostile terms. Tensions erupted as Barre began to use coercive force against the Majerteen clan, the tribe from which most of the opposing military officers came. NGOs report that more than 50000 people were killed during the reign of Siad Barre, with such actions eventually plunging the entire country into civil war in 1990 (Mbugua, 2006:24).

\section{Roots and contributing causes of the civil war}

The Somali civil war can be ascribed to a number of multiple and complex factors, of which Elmi and Barise (2006:34) have identified three main causes. Prominent amongst these is Somalia's colonial legacy. While the "decolonization process created large numbers of new territorial states in the European image ... for the most part it neither took account of existing cultural and ethnic boundaries, nor created new nations to fit within them" (Buzan, 1991:98). The second factor fuelling the conflict was the competition for power and resources among the various clans and militia groups. Here the control of key cities, ports and airports, checkpoints, agricultural areas and foreign aid became heavily contested resources amongst vying militia groups and various clans. As attested to by a Somali shopkeeper interviewed in Stellenbosch in July 2007, "Life is rough in Somalia, when I lived there everybody wanted to control the country. Everybody wants to be kings". Thirdly, state repression fuelled resistance. For 21 years, the military regime used excessive force and collective punishment to suppress opposition, with little regard for human rights. Inevitably, when the opportunity arises, repression leads to resistance.

Besides these factors, various socio-economic contributing causes, such as high unemployment and elements of Somali tribal culture and clan identity, have contributed to the escalation of conflict during the civil war. The change from an emphasis on inclusive clan identities to that of sub-clan identities after 1992 (for example Darod or Hawiye to Harti, Mareehaan or Mudullood) have led to clan disputes and disagreements, while positioning members of a single clan against one another. Such changes in clan identities fuelled and prolonged the war in Somalia and have undermined social cohesion.

Although most Somalis are Muslim and many argue that Islam in itself revolves around peace, Elmi and Barise (2006:38) explain that three features of Somali culture 


\section{9}

fuel violence by rewarding punishment: clan rivalry, collective punishment and negative competition. Effectively, these features allow for the killing of a member of another clan or sub-clan simply because someone else from the other clan had killed a person from the perpetrator's clan. Such revenge killings have resulted in the death of thousands of people and continue to be a source of much discontent and displacement. This practice was confirmed by Somali immigrants interviewed in Stellenbosch who agreed that in Somalia, "it is all about tribal warfare". One shopkeeper from the Hassan clan commented, "My tribe is too small to defend itself, a lot of people from my tribe have left the country. I lost my big brother to tribal warfare."

In addition, the country is awash with weapons. During the civil war, the two superpowers, the former Soviet Union and the United States, competed to arm the former dictator, Said Barre, whilst Ethiopia ensured that all opposing groups were well catered for. While weapons were easy to come by, a meaningful education and employment opportunities remained few and far between. The despair of the youth with regard to these matters was exploited by political elites keen to pursue their own agendas.

\section{Missed opportunities}

To date, fourteen peace conferences have been held in various African cities as well as Yemen over the past 16 years to resolve the conflicts in Somalia. Such conferences are said to have failed because they focussed primarily on satisfying the needs of warlords and politicians, as opposed to the traditional clan leaders who wield the majority of popular power (Sanders, 2007:17). The civil war, together with state weakness and decades of economic decline, complicated foreign intervention in that international role-players were left with the question of how to intervene and with whom to negotiate (Schoeman, 2006:245). Following a failed US-led peaceenforcement mission in Somalia in 1993, the country ultimately experienced complete collapse.

Most notable amongst recent peace initiatives are the 2000 Arta Peace Conference and the Inter-governmental Authority on Development (IGAD)-led Somali National Reconciliation Conference of 2002, held in Kenya. Although the Arta Peace Conference resulted in the formation of the Transitional National Government (TNG), this body soon came to be seen as representing predominantly Hawiye interests, and it barely managed to extend its control and legitimacy beyond Mogadishu.

It was not until 2004 when President Abdullahi Yusuf's Transitional Federal Government (TFG) was established as a result of the Somali National Reconciliation Conference in Kenya that some sense of order and stability began to creep into sight. 
Largely viewed as the brain-child of Ethiopian diplomacy, and although receiving wide international support, it soon became apparent that the new Darod-led government would meet with a hostile reception in Hawiye-dominated Mogadishu. After much delay and internal bickering, the TFG opened its first transitional parliament in Baidoa. However, a few of the warlords incorporated within the new government continued to pursue their own interests, demonstrating little regard for the surrender of their private militia forces or sources of revenue (Cornwell, 2007a).

By the beginning of 2006, Somalia was once again on a one-way collision course and the TFG became an impalpable entity, widely regarded as an imposed government not having been elected by the people of Somalia. This time round, a far greater threat than the warlords had begun to cast its shadow over the south of the country. Loose groupings of clan-based Islamic courts were gaining popularity for their ability to restore some sort of law and order. By May 2006, backed by the Saudi peninsula, but more importantly by Eritrea, the Islamic militias, termed the Union of Islamic Courts (UIC or Council), had displaced the Mogadishu warlords. The latter, in turn, were financed by the USA in its campaign against the threat of Islamic terrorism (Cornwell, 2006).

Although initially pleased by the UIC ability to regain some measure of control, Abdullahi Yusuf became increasingly concerned when the Islamic militants started expanding their influence, often without resistance, beyond Mogadishu. Within no time, much of the country, except for a small area around Baidoa, had fallen to the UIC, but this was short-lived (Witness, 2006:8). Blatantly violating international law, Ethiopia invaded Somalia in December 2006 (Bost, 2007:26). Prompted by calls for Islamic fighters to join what it termed its jihad or holy war against Ethiopia, the Ethiopian Prime Minister explained that his country was "forced to enter a war" with the Council (Daily Dispatch, 2006:8). Significantly, the Council had made it clear that they intended to reunite ethnic Somalis living in Ethiopia and Kenya with their supposed motherland. To crush the Council, Ethiopia launched a three-pronged assault on the Islamic militias who were unable to resist the well-armed conventional forces of Ethiopia. With the quick reinstallment of Abdullahi Yusuf in the capital, the USA welcomed the defeat of the UIC, following through with aerial attacks on suspected al-Qaeda hideouts in the south of Somalia (Cornwell, 2007a).

\section{The aftermath of TFG reclaim}

At present, the Darod-led TNG remains marginally in control of the capital, although conflict continues to simmer concerning the continued presence of the Ethiopian army in Somalia. Ethiopia's Prime Minister, Meles Zenawi, had said at the time of their swift advance in December 2006 that his troops would leave Somalia 


\section{1}

within a few weeks, although more recent reports suggest that the Ethiopian army will only pull out once a substantial peacekeeping force has been deployed to take its place (BBC News 24, 2007b). Numerous outbursts of violence between Ethiopian forces and Somali insurgents continue to occur, this despite the Somali government's claim in May 2007 that the four-month long campaign against Islamist insurgents, largely backed by Mogadishu's Hawiye clan, had finally been pacified (Nordland, 2007:6). Mogadishu witnessed its heaviest fighting in April and May 2007. More than 2000 Somalis were killed and UN refugee agency reports indicate that during this period more than $60 \%$ of Mogadishu residents were forced to leave their homes (BBC News 24, 2007a). Somali civilians, ever the brunt-bearers of urban warfare, place blame on all sides of the power struggle.

While allegations of Ethiopian excesses in the capital have been dismissed by Ethiopian Foreign Minister, Tekede Alemu, the Deputy Prime Minister of the TFG, Hussein Mohamed Farah Aideed, has accused Ethiopian troops of committing genocide against the Somali people during bouts of heavy fighting in the capital (Adam, 2007:19). Despite TFG criticism of brutal Ethiopian tactics, its insistence on labelling its opponents as "terrorists" and the recent massive loss of civilian lives in Mogadishu have made it "almost impossible for the TFG to depict itself as an impartial arbiter in national affairs" (Cornwell, 2007c).

At the time of writing in 2007, a humanitarian crisis is imminent as international aid agencies are hampered in their efforts to distribute vital humanitarian aid in the capital, as armed bandits pillage, loot and rape the masses of defenceless refugees (mostly women and children) fleeing the capital. The TFG and the Ethiopian Army too have been labelled "uncooperative" in promoting aid efforts, "closing airports, demanding visas for aid workers, levying 'taxes' at checkpoints" (Nordland, 2007:60). Similar difficulties have been experienced by the United Nations High Commission for Refugees (UNHCR), who claims that efforts to access supplies kept in the warehouses in the city have been considerably hampered (Kwayera, 2007:16). The situation has been exacerbated by Somali piracy on Somalia's lawless coast. On 19 May 2007, a failed hijack attempt on a World Food Programme (WPP) boat, killing a Somali guard on board, resulted in the refusal by aid ships destined for Somalia to leave port in Kenya. Notably, such attacks all but disappeared during the six months of strict UIC rule (Star, 2007b:5).

Although a UN Security resolution was passed in January 2007 endorsing an African Union decision to deploy an AU peace-keeping mission in Somalia (AMISON), and while Uganda, Nigeria, Ghana, Burundi and Malawi had all pledged to send troops, by January 2008 only the 1600 strong Ugandan contingent from a planned 8 000-strong force had set foot on Somali soil (Kaggwa, 2007:12; UNSC, 2007). After reports of fatal Ugandan casualties, successful calls for other AU 
countries to deploy peacekeeping troops to Somalia seem unlikely (Cornwell, 2007b). Thus, as the Ethiopian forces stationed in Somalia continue to stir the hornet's nest, such forces are finding it extremely difficult to disentangle themselves without being reinforced by an additional AU force to replace the weakened Ugandans. Putting aside all good intentions to provide African solutions to African problems, scepticism exists whether the AU itself is even financially or managerially up to the challenge. Despite this criticism, it appears as if the Ugandan contingent has done well to guard Mogadishu's airport and seaport as well as some other key government facilities (Morolong, 2007:6).

Although the UN is examining the possibility of deploying a peacekeeping force of its own, Cornwell (2007c) argues, "even given the best will in the world, it would take months to put a UN force on the ground". The UN has indicated that such a peacekeeping mission will only become possible once hostilities in south-central Somalia have ceased, and all armed groups have signed an agreement allowing for external monitoring (AU Peace and Security Council, 2007). On 20 August 2007, the UN Security Council passed Resolution 1772, supporting the extension of the AU mission to Somalia for a further six months. Simultaneously calls went out for UN Secretary-General Ban Ki-moon to continue developing the existing contingency for the possible deployment of a UN peacekeeping operation to replace AMISON, while urging all African states to pledge more troops (UNSC, 2007).

Various other African organisations have remained altogether opposed to the idea of an African force in Somalia, with IGAD, a regional body operating within the area, remaining divided on the issue (Thompson, 2007:11). Illustrating the regional divide, Eritrea has recently pulled out of IGAD after a rift with Ethiopia over Somalia, each of whom have accused the other of stirring the conflict (Star, 2007a:4). Eritrea's withdrawal presents a blow to diplomatic efforts to unite foreign opinion on establishing calm within Somalia.

\section{Internal and external role-players and factors undermining peace, stability and democracy}

Based on the evidence before us, as well as an analysis presented by Morolong (2007), we find that numerous role-players can be identified, and that Somalia needs to overcome a number of obstacles.

The TFG remains a weak administration. More recently divisions within the party have been deepened by divisions within the TFG executive. By mid-2007, the Somali parliament began to demand a substantive role in holding Prime Minister Ghedi accountable for his actions. Furthermore, as stated by Cornwell (2007d), "differences between Ghedi and President Abdullahi Yusuf were papered over to 


\section{3}

ensure mutual survival in the unpromising region of Mogadishu and its environs, but re-emerged in public disputes over oil exploration contracts signed with Chinese entrepreneurs, of which the prime minister claimed no knowledge." These actions culminated in the resignation of Ghedi and the appointment of Nur Hassan Hussein as Prime Minister in November 2007, a move praised by UN Special Representative for Somalia, Ahmedou-Ould-Abdallah because of its relatively peaceful conclusion (UNPOS, 2007). The TFG continues to be perceived, especially by the Hawiye clan, as a means of satisfying the interests of the Darod clan, while the TFG itself sees the UIC as its primary foe, and remains unwilling to include the UIC in any political settlement (Morolong, 2007:3).

Meanwhile, the UIC leadership, based in Asmara, Eritrea, has vowed to continue its campaign against the TFG until the Ethiopians are withdrawn from Somalia. The military wing of the UIC, the al-Shabaab, has already claimed responsibility for much of the attacks on the TFG and Ethiopians. Many of the fears concerning the UIC have centred on the UIC's Islamist ideology and supposed links to al Qaeda. Although the UIC has consistently denied links to Al Qaeda, some of the more radical leaders of the UIC, including prominent leader, Sheikh Haasan Dahir Aweys, have been linked to terrorist activities in the region and are mentioned on the US and UN list of terrorists (Morolong 2007: 4).

More strong opposition to the TFG can also be found in the self-declared independent region of former British Somaliland, a region, which the TFG refuses to recognise as an independent entity. Together with sporadic incidences of violence against the semi-autonomous Puntland, stronghold of President Yusuf, concerning the disputed areas of Sool and Sanaag, any foreseen attempts at full-scale war are likely to draw the TFG on the side of Puntland and the UIC or Eritrea on the side of Somaliland (Morolong, 2007: 5).

The conflict in Somalia has generated numerous inter-regional and intercontinental opinions, with various nations having taken sides in support of either the UIC or the TFG. Several role-players, playing a significant role in the continuation and maintenance of the conflict, include Ethiopia, Eritrea, Uganda, Kenya and Egypt within the regional realm, and the US, European Union (EU), China, Saudi Arabia and the International Contact Group on Somalia amongst the list of international stakeholders. It is generally believed that peace within the Horn of Africa will only come about should these actors be united in their goal of creating and maintaining stability (Morolong, 2007:14).

Ethiopian military presence in Somalia is considered the primary bone of contention amongst the opposition, and has resulted in increased resentment towards the TFG. Although throughout historical recounts the Somalis and Ethiopians have 
had unstable and poor relations, more recently -

this meddling has given shelter and arms to spoilers (groups and individuals). It has undermined the two most important peace accords (the Cairo Accord 1997, and Arta Agreement 2000) and has manipulated the Somali peace process in Kenya and the transitional government that was formed (Elmi \& Barise, 2006:39).

Just as in the case of Eritrea, Ethiopia too uses Somalia as a second front in its border dispute with the former, having promptly rejected international ruling concerning location of the border (ICG, 2007: 6; ReliefWeb, 2005). As Ethiopian Army presence in Somalia continues to remain problematic, and as Ethiopia strives to prevent a flow of radical Islamists from entering its borders, many Somali locals have suggested that Ethiopia, a powerful and well-positioned state, has systematically endeavoured to maintain a weak and divided Somalia.

Eritrea has been most vocal of its support for the opposition of the Ethiopianbacked TFG, and continues to provide such elements with political, financial and military support. More recently, this aid has come in the form of the provision of a safe haven for the UIC leadership in Asmara. The Eritrean government has become increasingly frustrated with the international community for its failure to pressure Ethiopia to accept the Ethiopia-Eritrea Boundary Commission of April 2002 (Morolong, 2007:5). The physical demarcation between the two countries was due to start in May 2003, but has now been postponed indefinitely. (ReliefWeb, 2005).

Uganda, on the other hand, continues to enjoy patronage from the US as part of its "coalition of the willing" against global terrorism (Morolong, 2007: 6). Persuaded by the US to deploy troops in Somalia, Uganda has thus far been the only country to fulfil its promises to the $\mathrm{AU}$, this despite fierce dispute within the Ugandan parliament concerning their deployment to Somalia (Monitor, 2007). Kenya, however, in an attempt to maintain "good neighbourliness" has refused to be drawn into a conflict with the people of Somalia, and closed its border with Somalia in January 2007 in an effort to stem the flow of militants and terrorists into Kenya (UNHCR, 2007; Morolong, 2007: 6). Together with the current crisis in Kenya after the so-called "rigged" election of December 2007, any possible role that Kenya might have fulfilled as peace-broker has been severely compromised. Fears also remain that aid agencies in Somalia will now have to divert their attention to help the many stranded and displaced Kenyans, tens of thousands of whom have been cut off from supplies as the crisis has closed down shops and transport across Kenya (Star, 2008:1).

Two of the biggest actors on the international scene include the US and the EU. Whilst the USA's commitment to uplifting the nation and promoting good governance remains insufficient, it continues to maintain strategic interests in Somalia, with an 
overwhelming focus placed on counterterrorism. The US led a UN force in Somalia when Mohamed Siad Barre was overthrown in 1991, but departed promptly two years later after 18 US soldiers were killed (Thompson, 2007:11). After September 11, in its fight against terrorism the US froze the assets of a large telecommunications network in Somalia, while blacklisting some 20 Somali companies as terrorist organisations (Elmi \& Barise, 2006:44). Using Al Qaeda as a pretext, the United States pushed Ethiopia, the US's closest ally in the Horn, into Somalia and has since followed through with indiscriminate bombings of villages that have left many innocent dead, with limited proof that alleged terrorists have even been found (City Press, 2007: 1).

Thus US intervention could be viewed as either a boon or burden in the effort to rebuild Somalia. While the US has boldly announced a commitment to ensuring that a "new age of peace and prosperity dawns on the Horn of Africa", it continues to embark on a thorough militarisation of its foreign-policy engagement with the African continent (Bost, 2007:26). Although the US has more recently urged reconciliation talks incorporating all Somali stakeholders, it has thus far demonstrated limited interest in helping to reconsolidate Somali state-building processes and institutions.

The EU meanwhile has placed priority on achieving peace, security and development in Somalia and has provided substantial financial support to both the Somali Reconciliation Conference in Kenya as well as the most recent Somali National Reconciliation Conference, which ended on 30 August 2007. With pressure from the EU to initiate an inclusive reconciliation process, the EU has also called for an investigation into the excessive use of force by Ethiopian troops in Somalia, the results of which remained unknown at the time of publication (Adam, 2007:19). Along with representatives from the US, AU, IGAD and the League of Arab States, the EU forms part of the International Contact Group on Somalia, an organisation established with the purpose of supporting peace and reconciliation in Somalia so as to ensure that "all parties comply with international law" (Hassan, 2007:5). According to a news brief published by the International Contact Group on Somalia in June 2007, this group has more recently called for an expansion of peace-keepers in Somalia and has condemned Eritrea for its role played in the continued supply of arms to Somalia (Morolong 2007:10).

\section{Current measures to resolve conflict and restore peace}

While the vision of Somalia obtaining immediate and lasting peace after decades of conflict seems far-fetched, talks continue in the hope of bringing some measure of stability to the Horn of Africa.

The Somalia National Reconciliation Congress has come and gone without much to show for all the hopes and financial support invested in this conference. Thrice 
postponed (officials had stated that the main reason for the delay was to accommodate demands by Mogadishu's Hawiye-i clan for more time to prepare and talk to the government) and partially overshadowed by grenade attacks in a market place in Mogadishu on 18 July 2007, foreign diplomats had believed the conference to be the best way to try to secure lasting peace in Somalia (Star, 2007c:1, Reuters Alertnet, 2007). Despite international pressure and conditionalities to involve all parties, including the UIC, within an inclusive intra-Somalia political process, and although the conference did manage to bring together and build a certain measure of consensus amongst clan elders, notables, respected personalities, religious leaders and previous political leaders, invitations were never extended to leading UIC personalities, including Sheikh Sharif Sheikh Ahmed, chairman of the Islamic Courts (Sanders, 2007:17).

Little doubt exists that the UIC was and still is popular amongst the citizens of Somalia, of whom more than $80 \%$ are Muslim. To some extent, the UIC did manage to reduce Somalia's notoriety as a collapsed state (Witness, 2006:8). Its main achievements were the removal of clan-based banditry from Mogadishu, the restoration of security and the provision of conditions for the revival of business. The UIC represents a genuine constituency and it is becoming increasingly clear that for any length of peace to ensue, the UIC cannot continue to be ignored by the Somali government, who for long have refused to enter into dialogue with the courts and "insurgents" (Nieuwoudt, 2007:17).

Thus, in a shift away from addressing critical political issues and the reform of government, and in a move to avoid the development of any consolidated political challenge, the TFG opted instead to convene a clan-based process of reconciliation focussing on social and tribal disputes during the recent Somalia National Reconciliation Congress. While issues concerning a ceasefire, Somali clan forgiveness, disarmament, return of stolen properties and the setting up of a council to undertake the interpretation of religious matters were discussed, few tangible steps were taken to show how such ideals might be implemented in practice (Cornwell, 2007d). Although the resolutions of the conference were somewhat vague with regard to how power-sharing within the Somali government would take place in future, a statement issued by the Congress suggests that

parliament should amend the Federal Transitional Charter in such a way that paves the way for the formation of an efficient government chosen from the public or the parliament given full consideration to the education, efficiency, experience, transparency, good behaviour and patriotism. (Council on Foreign Relations, 2007)

The Congress furthermore recommends, "the anticipated government should be 


\section{7}

inclusive of all clans and based on the real political power sharing in conjunction with the transitional charter". A date was set for the performance of "free and fair elections before the end of the term of the TFG in the year 2009". Only time will tell whether such good intentions will come to pass.

If anything, the only result of any substance to the congress has been a more united and organised opposition to the TFG. Convened on 6 September 2007 in an attempt to run parallel to that of the Somalia National Congress, political opposition groups organised their own alternative conference in Asmara, Eritrea. With members of the Islamic courts, Somali nationalists, religious scholars, civil society and exmembers of the TFG in attendance, parties appeared to agree on the need for the rejection of all clan-based approaches to any future democracy, as well as the need for the immediate withdrawal of Ethiopian troops. Issues concerning the nature of the Somali state to be reconstituted as well as whether the removal of Ethiopian forces should take place via diplomatic or military means remain unresolved (Cornwell, 2007d). Soon after the conference, an opposition alliance headed by UIC leader, Sheikh Sharif Aheikh Ahmad was formed (BBC News 24, 2007b).

\section{Prospects for peace, security and democracy}

As Morolong (2007) asks, have all the options run out? What exactly are the prospects of a functioning democracy for Somalia?

On her visit to Somalia in May 2007, Italian Deputy Foreign Minister, Patrizia Sentinelli, stated, "security can only be realised through a ceasefire" (Cornwell, 2007c). Also important, however, is that successful democratisation can only be achieved by means of a basic level of so-called "stateness" and effective administration. Little can be gained from holding mass elections in the absence of a rule of law, a functioning bureaucracy and one's personal safety (Bratton, 2005:12). The World Bank Institute's (WBI) governance indicators evaluate a state's weakness or strength along five dimensions: government effectiveness, political stability, regulatory quality, control of corruption and rule of law. Taking such indicators into account, "Somalia brings up the rear with its extremely low performance on the rule of law and the displacement of economic policy by looting" (Bratton, 2005:13). Against this background, it is clear that the challenges to peace, stability and democracy continue to remain vast and innumerable.

Mbugua (2004:31) suggests that for democracy building to take place, the following must exist:

- The new leadership must find a balance between Somali nomadic traditions, modern developments in governance as well as the Islamic 


\section{8}

religion and its tradition.

- The process of state rebuilding must incorporate mechanisms for unifying the Somali people.

- The structure of government ought to incorporate several branches so as to provide for a municipal form of governance.

- The state must envision a programme whereby the many independent militias are consolidated into one national military force with the aim of controlling the weapons in their hands.

- The rural areas must be de-mined whilst a need also exists to reconstruct public infrastructure.

- Monumental challenges remain in terms of "containing the secessionist tendencies within regions and the loyalties of past autocracies, and reintegrating them under one government, constituting a national police force, formulating a national education system, minting a national currency and establishing a central bank. Of course, central to the process is the nurturing of democratic institutions such as broad-based political parties, civil society and the media".

In addition, incentives are needed to encourage skilled Somalis to remain within the borders of the country, or alternatively return to the country of their birth. Limited hope remains for the economy if most of the Somali human and social capital continues to reside within countries such as South Africa, Kenya and Tanzania. Among the shop-keepers interviewed for this study, the causes given for immigrating to South Africa were two-fold: the need to escape the poverty and destitution in Somalia as well as the political instability and civil war. There was general agreement among the shop keepers that, "There is no work and no life in Somalia." While many of Somalia's skilled labour force has opted to immigrate, large portions of the country lack basic education.

Unless genuine political goodwill (thus far lacking on the part of the TFG) is coupled with a phased peace process, it can be anticipated that sporadic episodes of violence are likely to continue in Mogadishu. Under such circumstances, a ceasefire becomes problematic if not impossible. What is blatantly obvious, however, is that military solutions will not ensure lasting peace. A simple replacement of one military force with another is not the answer. Cornwell (2007c) warns that the AU must be at pains "not to be seen as a surrogate for the hated Ethiopians, or its potential role as honest broker will be forfeited in much the same way as has happened in Darfur".

As it is, Morolong (2007:12) suggests three future scenarios for Somalia. The 
first involves the progression of the status quo with increased tensions between Ethiopia and Eritrea, while the second concerns Ethiopian withdrawal (that is, counting on external pressure), with the possibility of a power vacuum evolving unless every effort is made to deploy a fully functioning AU or UN peacekeeping force. The third predicts the increase of opposition momentum, coupled with and leading to full-scale regional conflict. As Morolong (2007:13) suggests, we may well be "staring into the abyss of war".

However, not all is lost. Utilisation of the unique assets particular to Somalia and the Somali people is needed. Elmi and Barise (2006:50) suggest that in rebuilding trust and confidence amongst Somali groups and individuals, any peace education efforts should draw upon Islam, a religion which ultimately revolves around peace and which incorporates the overwhelming majority of Somali citizens. "Islaminformed peace education would stress the kinds of values and behaviours that would unite the Somalis as Muslims in a bond of brotherhood, mutual love, sympathy, help, care and fellow-feeling" (Elmi \& Barise 2006:52). The use of Islam as a means of inducing peace-building activities presents a vital tool, which has thus far been underutilised by both national and international role-players, although it was mentioned in a recent statement released by the Somalia National Congress. According to this statement, "the role of moderate religious leaders should be recognised and they should be given the opportunity to participate in the restoration of peace ..." (Council on Foreign Relations, 2007).

Popular Somali opinion exists that should tribal leaders be willing to negotiate a real attempt at reconciliation, tribal militants may become more pliable in the hands of the government. As reaffirmed by one of the Somali immigrants interviewed, "Only the tribal leaders can create peace. If they can sort out the problems of the country between them, the people of Somalia will follow in their lead."

Moreover -

the reality of hostile ethnic politics in the Horn of Africa - a common religion, language, culture and identity, and the presence of an external enemy that is determined to exploit their weakness - has convinced the Somali people that ending the protracted conflict and creating a united and strong Somali government is necessary for their survival in that part of the world (Elmi \& Barise, 2006:53).

From the above, it is clear that there are divergent views on how peace and stability can be achieved in Somalia. Although it would seem that a form of democracy, which embraces a clan-based formula as opposed to a faction-based formula, may well be rejected by opposition movements in Somalia, it could also prove successful in enlisting the support of the general public. Some of the younger 
Somalis interviewed in Stellenbosch claimed that attempts need to be made to "detribalise" Somalia, so allowing for a one-party one-vote Western form of democracy. Older Somalis felt that the tribal system in Somalia would never die. Yet with the removal of Ethiopian troops combined with the help of an inclusive, phased and comprehensive conflict resolution process incorporating dialogue, implementation and consolidation/normalisation measures, some form of a democratic government may yet be within the reach of the Somali nation within the next few years, if not within the next few months. At the moment, all depends on hopes that the current government may be persuaded to include opposition movements within planned peace processes, and that urgent international support may be directed towards war-torn Somalia, with a strengthened AU or even hybrid AU/UN peacekeeping force. Non-African states should, however, not only provide numbers, but also appropriate logistical support and other force multipliers (ICG, 2007: 13) and keep in mind the deep suspicion many Somalis have of external influences and agendas, and as well as the needs of the Somali civilians.

\section{Concluding remarks}

In Africa's weak states, a move towards democracy represents the best hope for peace and prosperity. Yet the minimum requirement for democracy to succeed is some measure of sustained stability and, in an effort to promote economic growth, the development of sustainable political institutions as well as the nurturing of a culture of democracy. However, before Somalia can think of developing, let alone sustaining or consolidating some form of democratic rule, all must agree on the rules of the game. At present, the constant interference of outside parties, including Ethiopia and Eritrea, ongoing clan rivalry and unwillingness of the TFG to negotiate with opposition movements, make it impossible for parties to reach consensus and to build the necessary state institutions needed to sustain a democracy. Here Somalia lacks an essential ingredient vital for democracy, a so-called sense of "stateness", which includes a professional civil service, an effective legislature, executives and electoral system. Disappointingly, it would appear as if the recent Somalia Reconciliation Conference does not represent the foundation for the establishment of such measures to encourage unity and the adoption of democratic values.

In seeking a solution to the present conflict, one needs to grasp the historical and social dynamics that continue to create tension within this society. This may include a closer look at the so-called "uncontrollable nature" and "inherently militant personality" of the Somali psyche. Moreover, the TFG certainly has something to learn from the positive strides forward taken by partly successful UIC governance in 2006. 


\section{1}

\section{References}

Adam, H. 2007. Ethiopians 'guilty of genocide'. Mail and Guardian, 10 May:19.

AU Peace and Security Council. 2007. Report of the Chairperson of the Commission on the Situation in Somalia. $80^{\text {th }}$ meeting, Addis Ababa. 18 July.

BBC News 24. 2007a. Somali UN peace force considered, 19 March. Available at: http://news.bbc.co.uk/1/hi/world/africa/7304275.stm (accessed 2 February 2008).

BBC News 24. 2007b. Somali clan unity deal rejected, 17 September. Available at: http://news.bbc.co.uk/1/hi/world/africa/6999252.stm (accessed 20 December 2007).

BBC News 24. 2007c. Ethiopia ‘bogged down' in Somalia, 27 November. Available at: http://news.bbc.co.uk/1/hi/world/africa/7114979.stm (accessed 20 December 2007).

Bost, E. 2007. US policy on Africa is ominous, Sunday Times. 8 February:26.

Bratton, M. 2005. Building democracy in Africa's weak states. Democracy at Large, 1(3):12-15.

Buzan, B. 1991. People, States and Fear: an Agenda for International Security Studies in the Post-Cold War Era. Hertfordshire: Harvester Wheatsheaf.

City Press. 2007. Tempting, but SA cannot join proxy war in Somalia. 14 January. Available at: https://www.samedia.uovs.ac.za/cgi_bin/getpdf?year= 2007\&refno=429\&topic $=45$ (accessed 19 April 2007).

Cornwell, R. 2006. Somalia: Distorting reality? African Security Review, 15(2):76-78.

Cornwell, R. 2007a. Somalia: What prospects for stability? Centre for International Political Studies. Electronic briefing paper. University of Pretoria. No. 07.

Cornwell, R. 2007b. Commentary to: Guns silent in Mogadishu, hundreds thought dead. ISS Today. Available at: http://www.issafrica.org/ inde.php?link_id=14\&slink_id=4264\&link_type=12\&slink_type=12\&tmpl_id=3 (accessed 1 June 2007).

Cornwell, R. 2007c. Commentary to: Italy urges reconciliation, ceasefire in Somalia. 
ISS Today. Available at: http://www.issafrica.org/static/templates/tmpl_html.php? node_id=2248\&link_id=29 (accessed 1 June 2007).

Cornwell, R. 2007d. Somalia collapsing inwards. ISS Today. Available at: http://www.issafrica.org/index.php?link_id=5\&slink_id=5086\&link_type=12\&slink_t ype=12\&tmpl_id=3 (accessed 20 December 2007).

Council on Foreign Relations. 2007. Somali National Reconciliation Conference decisions. Available at: http://www.cfr.org/publication/14263/ (accessed 3 December 2007).

Daily Dispatch. 2006. No end to this conflict. 27 December: 8. Available at: https://www.samedia.uovs.ac.za/cgi_bin/getpdf?year=2006\&refno=4464\&topic $=45$ (accessed 19 April 2007).

Elmi, A.A. \& Barise, A. 2006. The Somali conflict: Root causes, obstacles, and peace-building strategies. African Security Review, 15(1):32-54.

Hassan, H. 2007. Somalia torn apart by clan rivalry. Weekender, 8 April 2007:5.

Heywood, A. 2002. Politics. Basingstoke: Palgrave Macmillan.

International Crisis Group (ICG). 2007. The tough part is ahead, Africa Briefing No. 45, 26 January. Available at: http://www.reliefweb.int/rw/rwb.nsf/db900sid/LSGZ6XTKD5?OpenDocument (accessed 3 December 2007).

Kaggwa, A. 2007. Ugandan troops head for Somalia. City Press, 4 March:12.

Kwayera, J. 2007. Peace slips from Somalia's grasp. Mail and Guardian, 3 May:16.

Mbugua. K. 2004. Prospects for peace and state rebuilding in Somalia. Conflict Trends, 1:25-31.

Mbugua, K. 2006. Situation report: Somalia. Conflict Trends. Available at: http://journals.sabinet.co.za/webZ/images/ejour/isafsec/isafsec_vis_n1_94.pdf?session $\mathrm{id}=01-49108-652572783 \&$ format=F (accessed 20 April 2007).

Monitor. 2007. Uganda; Ruling party MPs block attempt to rush Somali deployment, February 1. Available at: http://www.benadirwatch.com/2007\%20News/0201_ Ug_MPs_block_deployment_attempt.pdf (accessed 20 December 2007). 


\section{3}

Morolong, H. 2007. Situation report: Somalia, have all the options run out? Institute for Security Studies. Available at: http://www.iss.co.za/ dynamic/administration/file_manager/file_links/SITREPSOMALIANOV07.PDF?link _id=\&slink_id=5142\&link_type=12\&slink_type=13\&tmpl_id=3（accessed 3 December 2007).

Nieuwoudt, S. 2007. Darfur and Somalia hobble AU summit. Mail and Guardian, 8 February:17.

Nordland, R. 2007. 'Not absolutely' normal. Newsweek, 28 May:60.

Ohlson, T. \& Soderberg, M. 2003. From intra-state war to democratic peace in weak states. Available at: http://www.pcr.uu.se/publications/UPRP_pdf/UPRD_No_5.pdf (accessed 21 April 2007).

ReliefWeb 2005. 2005. Eritrea: border deadlock and underfunding perpetuate IDP plight, 17 June. Available at: http://www.reliefweb.int/rw/rwb.nsf/db900sid/LSGZ6DFDD2?OpenDocument (accessed 20 December 2007).

Reuters Alertnet. 2007. Somalia postpones peace conference for a second time. 13 June. Available at: http://www.alertnet.org/thenews/newsdesk/L13802269.htm (accessed 4 July 2007).

Sanders, E. 2007. Somali reconciliation congress set to heal 16 years of civil war. Sunday Independent, 15 July:17.

Schoeman, M. 2006. Africa's International Relations in Power, Wealth and Global Equity. Landsdowne: UCT Press.

Star. 2007a. Mogadishu's inhabitants lose hope amid conflict. 23 April:4.

Star. 2007b. There is no other work for us, says Somali pirate. 11 June:5.

Star. 2007c. Violence still mars Mogadishu peace talks. 19 July:1.

Star, 2008. Kenya running on empty. 8 January:1.

Thompson, D. 2007. Power vacuum in Somalia as Islamists driven out. City Press, 7 January. Available at: https://www.samedia.uovs.ac.za/cgi_bin/getpdf?year=2007 \&refno=428\&topic=45 (accessed 19 April 2007). 


\section{4}

UN High Commissioner for Refugees (UNHCR). 2007. Somalia: Thousands have recently fled capital, plight of those remaining becoming desperate. UNHCR Briefing Notes. 3 April. Available at: http://www.unhcr.org/news/NEWS/461232454.HTML (accessed 4 July).

UN Security Council (UNSC). Resolution 1744 (2007): The situation in Somalia. Available at: http://daccessdds.un.org/doc/UNDOC/GEN/N07/245/31/ PDF/N0724531.pdf?OpenElement. (accessed 30 June 2007).

United Nations Political Office for Somalia (UNPOS). 2007. Press release: UN Special Representative welcomes nomination of new Somali Prime Minister, 22 November. Available at: http://www.un-somalia.org/ (accessed 10 December 2007).

Witness. 2006. Horns of a dilemma. 29 December: 8. Available at: https://www.samedia.uovs.ac.za/cgi_bin/getpdf?year=2006\&refno=4466\&topic $=45$ (accessed 19 April 2007). 